Article

\title{
EU Armed Forces' Use of Social Media in Areas of Deployment
}

\author{
Maria Hellman, Eva-Karin Olsson and Charlotte Wagnsson * \\ Department of Security, Strategy and Leadership, Swedish Defense University, 11593 Stockholm, Sweden; \\ E-Mails: maria.hellman@fhs.se (M.H.), eva-karin.olsson@fhs.se (E.-K.O.), charlotte.wagnsson@fhs.se (C.W.) \\ * Corresponding author
}

Submitted: 28 May 2015 | Accepted: 3 November 2015 | Published: 18 February 2016

\begin{abstract}
The advent of social media can be seen both as a risk and an opportunity by armed forces. Previous research has primarily examined whether or not the use of social media endangers or strengthens armed forces' strategic narrative. We examine armed forces' perceptions of risks and opportunities on a broad basis, with a particular focus on areas of deployment. The article is based on a survey of perceptions of social media amongst the armed forces of EU member states, thus adding to previous research through its comparative perspective. Whereas previous research has mainly focused on larger powers, such as the US and the UK, this article includes the views of the armed forces of 26 EU states, including several smaller nations. In analyzing the results we asked whether or not risk and opportunity perceptions were related to national ICT maturity and the existence of a social media strategy. The analysis shows that perceptions of opportunities outweigh perceptions of risks, with marketing and two-way communication as the two most prominent opportunities offered by the use of social media. Also, armed forces in countries with a moderate to high ICT maturity emphasize social media as a good way for marketing purposes.
\end{abstract}

\section{Keywords}

armed forces; EU; international deployments; social media

\section{Issue}

This article is part of the issue "Peacebuilding in the Age of New Media", edited by Vladimir Bratic (Hollins University, USA).

(C) 2016 by the authors; licensee Cogitatio (Lisbon, Portugal). This article is licensed under a Creative Commons Attribution 4.0 International License (CC BY).

\section{Introduction}

This study surveys and analyzes diverging views amongst EU armed forces on the risks and opportunities of social media use in areas of deployment. Social media pose significant challenges and call for the management of issues such as transparency of information and communication with local populations. The use of social media also raises concerns about the security of deployed troops. Social media have been in use in armed forces since the Kosovo crisis in 1999 (Nissen, 2015, p. 8). The increasing use and importance of social media, alongside intensifying debate about the reliance on communication for successful multinational military interventions, give us cause to explore the views of EU armed forces on the use of social media. These forces participate together on multinational operations, and their views on the management of the information flows of social media pose increasing problems for coordination and collaboration, and for facilitating and improving their efficiency.

Social media can be used for multiple purposes. On the one hand, social media use might mirror traditional ways of thinking about communication as one-way communication originating from Shannon and Weaver's transmission model for telecommunication systems (Shannon, 1948). On the other hand, the use of social media could correspond with more recent views on two-way communication, influenced by digital technology (e.g. Dunleavy, Margett, Bastows, \& Tinkler, 2006). A study of the Swedish Armed Forces indicates that market logic is the key driving force for communication via social media; the Armed Forces are seen as an agency in various markets competing with other actors for personnel, influence, funding and political attention (Deverell, Olsson, Wagnsson, Johnsson, \& Hellman, 2015). The use of social media, primarily for 
marketing purposes, corresponds with a general trend within public organizations towards more market driven communication (e.g. Byrkjeflot \& Angell, 2007).

If armed forces place great value on the marketing potential of social media, they can choose to 'let go' of control. However, armed forces may seek to retain control of information to ensure its accuracy, and in order to prevent the spread of sensitive information that may jeopardize personal and operational security. Social media can indeed be a disruptive force for national narratives and government messages in the security sphere (Andén-Papadopoulos, 2009; Kahn \& Keller, 2004). Therefore, armed forces may instead opt to strengthen control and/or censor opposing narratives on social media platforms (Cammaerts, 2008; Morozov, 2011). Research indicates that social media have become more regulated and less free as armed forces have grown increasingly aware of the risks involved (Bennett, 2013, p. 49; Bjerg Jensen, 2011, p. 196; Cammaerts \& Carpentier, 2009; Lawson, 2014; Maltby, Thornham, \& Bennett, 2015).

However, scholars have paid little attention to how armed forces beyond the US and the UK have dealt with the 'social media challenge' (see for example Bjerg Jensen, 2011; Maltby et al., 2015; and Jones \& Baines, 2013, on the UK; and Rid \& Hecker, 2009, on the US, Great Britain and Israel). Previous research has mainly focused on whether or not armed forces have been harmed by or have managed to exploit social media, whether they have tried to control social media and to what degree they have allowed personnel to communicate freely via social media.

Social media provide armed forces with new opportunities to get their message out in areas of deployment. For instance, they might see great opportunities for marketing their operations via social media without having to involve news media. What is clear is that armed forces see an increasing need to communicate with a multitude of audiences through social media. Thus, military organizations disseminate official messages in a transformed media environment, engaging in social media through channels such as YouTube, blogs, Twitter and Facebook (Bennett, 2013, p. 49). In their study Caldwell, Murphy and Menning (2009), for example, examine the use of social media by the Israeli Army and Hezbollah during the 2006 Second Lebanon War. They argue that Hezbollah, as a result of skillful social media use, was successful, whilst Israel was perceived as having failed. '.... Hezbollah information efforts focused directly on gaining trust and sympathy for its cause at all levels. Israel provided no countervailing view, allowing Hezbollah to drive perceptions that could become universally accepted as truth' (Caldwell et al., 2009, p. 6).

Building upon previous research, this article fills a gap in the literature by taking a broader perspective and examining European armed forces' perceptions of social media use in areas of deployment. Moreover, we examine whether or not armed forces' perceptions of social media are connected to national ICT maturity and the existence of a social media strategy (see below). What this study particularly adds to previous research is its comparative perspective; it stands out from other studies by including views amongst the armed forces of almost all EU states, including all the smaller member states.

\section{Previous Research}

Participation in international missions in complex political, military and social environments, along with technological developments, have required armed forces across the Western world to develop new expertise in a range of areas, including communications (Forster, 2006, p. 6). The involvement of international organizations (NATO, UN) in a number of complex emergencies in recent years-e.g. Afghanistan, Libya and Mali-has required the ability to communicate across military and civilian boundaries, as well as with the populations in the countries in question. Participation in international missions also requires communication with a nation's own citizens in order to muster popular support for perilous military interventions. Despite all this, there is limited research examining armed forces from a communication perspective. The research that does exist has concentrated mainly on aspects related to strategic communication, such as governments' transmission of strategic narratives (Bjerg Jensen, 2014; Jankowski, 2013; Ringsmose \& Börgesen, 2011). The academic debate has focused on social media both as a threat, and as an opportunity for armed forces to get their message across. For example, in a study of the use of social media by the Swedish Armed Forces, Deverell et al. (2015) argue for the advantages of social media use falling into three broad areas: one-way, two-way and market oriented communication.

Academics who understand social media primarily as an opportunity tend to emphasize the inherent potential of social media for disseminating the national strategic narrative in situations where armed forces have devoted substantial resources to developing their own media outlets (Bennett, 2013, p. 49; Karatzogianni, 2008, p. 2). This is so because success in the application of force depends ultimately on how the war, its purpose and its conduct are perceived at home and within the theatre of operations. The use of social media platforms by armed forces can impact positively on both recruitment and the legitimization of the tasks of armed forces. Wall (2006, p. 122) suggests that bloggers active during Gulf War II did not present alternative perspectives of the war, but offered more personal versions of prevailing public debate about the war. Personalized accounts by military personnel, encouraged to blog directly 'from the field', can be utilized to strengthen a national strategic narrative (Hellman \& Wagnsson, 2015). 
On the other hand, armed forces face several risks by using social media. Firstly, they risk losing control of their own narrative from a strategic management perspective (e.g. Jones \& Baines, 2013). From this perspective one threat arises from the use of social media by military personnel. Having investigated homemade videos uploaded to YouTube by coalition soldiers in Iraq and Afghanistan, Andén-Papadopoulos (2009, p. 17) suggests 'The soldiers' firsthand accounts of the war have introduced new and sometimes highly controversial perspectives into the documentation of warfare that military and media elites are struggling to contain'. In addition to harming the national strategic narrative, military personnel using social media in operational theatres can place their comrades or mission aims at risk. Academics in the field have, for example, stressed how increasing globalization, fueled by new information technology, has blurred the boundaries between combatants and non-combatants and between home and abroad (Betz, 2008). In such an environment it is important to understand that messages intended for domestic audiences may easily spread to the area of deployment and, similarly, locally targeted messages may be transmitted around the globe (Paul, 2012).

Besides the problems associated with communication by individual military personnel, another problem in trying to control the strategic narrative is the coordination of messages. For example, during the Afghanistan mission it was not until 2006 that the realization dawned 'that the communication strategy had to be aimed at all the relevant target groups-and that these were implicated with each other' (Dimitriu, 2012, p. 206). The problems associated with targeting several audiences at once were also illustrated during NATO's intervention in Libya in 2011, when British messages were primarily designed to legitimize the operation in the eyes of the domestic audience. As a result, there was a lack of consistent messages suitable for the needs of local civilians. Instead, messages formulated in NATO countries participating in the intervention unintentionally reached local audiences and became more of a hindrance than a help in building legitimacy for the operation (Bjerg Jensen, 2014, pp. 182-183).

There are also cultural and technical obstacles facing the use of social media by armed forces in areas of deployment. Despite the ambition to reach all the vital stakeholders with their communication, from global opinion to the local level on the ground, ISAF generally had a poor understanding of the Afghan population, due to difficulties in understanding local language, culture and history (COMISAF Initial Assessment, 2009). Beyond the problems associated with the cultural gap, there are also technical obstacles to communicating with the local population through social media due to low levels of Internet penetration (International Telecommunication Union, 2015). Due to low levels of Internet use, key leader engagement and radio became the most important sources of information. All the problems discussed above risk either distorting the strategic narrative, or impeding it from reaching its target group.

In the next sections we describe two explanatory factors, which we suggest may impact on armed forces' perceptions of social media: the existence of social media strategies and ICT maturity in a national setting.

\subsection{The Existence of Social Media Strategies}

Our first explanatory factor relates to the presence or otherwise of a social media strategy. As previously discussed, one important aspect of the military use of social media is the notion of control, which is often manifested in regulations and policies. Previous research indicates that the US armed forces' attitude to the use of social media has changed since the beginning of the century. Having been relatively liberal, views have become more restrictive following incidents that could have had a negative impact on US public opinion (Lawson, 2014). Until 2010 , social media rules and regulations were rather unclear and based on the need to ask superiors' permission before publishing information that could potentially endanger operations (Resteigne, 2010, p. 523). The trend in trying to increase control may be reinforced by the internal organizational logic likely to come into play when communication departments are given more resources. There is a general trend within public agencies towards professionalization and expansion of communication functions (Byrkjeflot \& Angell, 2007; Deverell et al., 2015; Wæraas, 2010). To sum up, public agencies, including armed forces, might consequently be inclined and/or expected to issue official policies and regulatory documents intended to increase control, and restrict the free use of social media. On the other hand, they may try to formulate social media policy so as to encourage and facilitate the use of social media for marketing the armed forces, thus loosening control, as previously argued. We investigate how the adoption of a social media strategy relates to negative/positive attitudes to the use of social media.

\subsection{ICT Maturity in National Settings}

Our second explanatory factor is the ICT maturity in armed forces' respective home countries. To our knowledge there is no previous research connecting an armed forces domestic level of ICT to perceptions of social media as a threat or opportunity in international missions. However, previous research demonstrates how the level of ICT maturity in various societies impacts on the use of social media. For example, based on a literature review of social media use in egovernment, Magro (2012) concludes that the digital divide is a major barrier to e-participation. A study by Bertot, Jaeger and Grimes (2010) shows that the level of ICT use in governmental agencies depends, not pri- 
marily on their own preferences regarding new information technology, but rather on citizens' preferences, and technical abilities, when interacting with governmental agencies. At the same time, and to their surprise, Bonsón, Torres, Royo and Flores (2012) found in their study of social media use amongst EU local governments that the national level of Internet access, and use by citizens, were not significant predictors of the level of the use of Web 2.0 and social media in local government.

Again, there are arguments for both positions. We can expect armed forces from countries with a social media savvy population (e.g. Sweden, Finland or Denmark) to have a more positive outlook on social media use in deployment areas. At the same time, despite the use of social media in humanitarian interventions and peacekeeping operations ranging from Kosovo to Afghanistan and Darfur, the chiefs of staff should still pay attention to the risks involved.

\section{Method}

The questionnaire that forms the basis of the empirical analysis was designed to capture views on social media use with a focus on risks and opportunities. All the armed forces of EU member states responded to the questionnaire, with the exception of Greece and Cyprus. Luxembourg was included in the study, but claimed not to use social media and responded to no more than a few questions in the questionnaire, which is probably due to the small size of the armed forces of this country.

We focused on views about social media at the highest, strategic, level of organization. When contacting the armed forces of individual countries, we asked them for contact with the Head of the Information Department, or another authoritative person who could express their official view of the use of social media within the Armed Forces. Half of the respondents are representatives of armed forces' information departments, one third are representatives of the Ministry of Defense and the remaining 18 per cent hold other positions, with tasks related to their armed forces' information and communication.

Policies issued at the strategic level are not always followed at lower levels of the organization or by individual services (army, navy, air force). Rid and Hecker (2009, p. 94) identify an "institutional gap" in Great Britain between the public affairs' leadership at the Ministry of Defense and the military command. They argue that the public affairs civilian leaders attempted to increase control in ways that were not conducive to practices at subordinate military levels. The authors $(2009$, p. 223$)$ recommend that military public affairs in ministries of defense should primarily be run by senior officers and not by civil servants, since these have better access to senior commanders. Our results, therefore, are an indication of the armed forces' overall objectives in using social media and do not necessarily fully reflect practices in the field.

These significant limitations mean that the findings presented and discussed here must not be overstated. More research is needed to provide a more thorough and solid picture of armed forces' views of-and use of-social media in peacekeeping operations at different levels of the organization. However, because this study includes responses from the armed forces of almost all EU states, it provides a useful starting point for future research.

Firstly, we asked a few general questions; namely, what types of social media the armed forces use, and their view as to whether or not social media mainly posed risks or presented opportunities, when used in an area of deployment. We also asked if they had issued a social media strategy. Indeed, armed forces, that have not adopted a social media strategy, may have other policies that regulate the use of communication by the agency and/or its personnel. A few indicated that this is the case. The Netherlands for example stated: 'We provide guidelines for using Social Media. Info opsec is forbidden to share. We hand out tips \& tricks for the use of social media.' However, this is not the same as having an elaborate general official view on social media use, which is valid as strategic guidelines for the entire organization.

In order to capture different types of opportunities/risks that we argue social media could offer/pose to armed forces, we formulated three risk and three opportunity statements. The statements of risk/threat read as follows: Personnel stationed in an area of deployment (for example Afghanistan) using social media platforms (for example blogs): a) Make the Armed Forces lose control and risk distorting information, making it less correct; b) Place soldiers at risk by revealing sensitive information; c) Harm mission purpose by revealing sensitive information.

The statements of opportunity are: Personnel stationed in an area of deployment (for example Afghanistan) using social media platforms (for example blogs): a) Are a good way to market the armed forces and its mission in the area of deployment; b) Facilitate oneway communication with the civilian population and is a good way to disseminate correct information about the armed forces; c) Facilitate two-way communication with the civilian population, increasing transparency of the operation.

The respondents were asked to grade each statement from "do not agree at all" (1) to "wholly agree" (5). When presenting the answers we merged the two answers indicating agreement, as well as the two answers indicating disagreement, which resulted in three categories of answers (disagree/neither disagree or agree/agree). The distribution of responses was then set against the two explanatory factors: ICT maturity in a national setting and the existence of social media policies in cross-tables. The explanatory factors were 
cross-tabulated against each risk and opportunity factor to explore relationships between them. In the presentation of the results we focus on those instances where a particular risk or opportunity was found to be related to an explanatory factor.

The ICT maturity factor was derived from the statistics of the International Telecommunication Union (2015) using the latest figures (from 2013) listing the share of population using the Internet. The armed forces were divided into three groups: firstly, armed forces from high ICT maturity countries with Internet use above $85 \%$ of the population: the Netherlands, Sweden, Finland, Denmark, Luxembourg and the UK. Secondly, armed forces from moderate ICT maturity countries with Internet use between 70 and $84 \%$ of the population: the Czech Republic, France, Ireland, Latvia, Slovenia, Estonia, Germany, Austria, Belgium, Slovakia, Hungary and Spain. And finally, armed forces from low ICT maturity countries with Internet use below 69\%: Lithuania, Italy, Croatia, Malta, Bulgaria, Poland, Romania and Portugal.

\section{Views on Social Media Use: Risk versus Opportunity}

\subsection{General Views on Social Media Use}

In this section we account for the general results of the survey that clarify views on the use of social media, as well as perceptions of risks and opportunities in relation to social media use.

The findings from our survey show that all the armed forces, with the exception of Luxembourg, claim to use social media; first and foremost Facebook, YouTube and Twitter. Some also name Instagram, Google+ and LinkedIn, but only a few say that they use blogs.

Only 11 of the armed forces claim to have an official social media strategy (Austria, Belgium, Estonia,
Finland, Hungary, Ireland, Italy, Romania, Spain, the Czech Republic and the UK). It is a recent phenomenon since, with the exception of Ireland (2008) and the UK (2009), these armed forces only issued a social media strategy in the last couple of years. Among those armed forces without a social media strategy, eight claim that they are planning to issue one (Bulgaria, Croatia, Denmark, Lithuania, Malta, Poland, Slovenia, and Sweden).

When asked about the opportunities and risks of social media use in areas of deployment, almost all of the European armed forces recognize that social media offer opportunities.

As can be seen in Figure 1, half of the armed forces acknowledge that there are problems and risks involved with social media use, but none perceives the risks as outweighing the opportunities when these are discussed in general terms.

Next we examine perceptions of specific risks and opportunities. Figure 2 shows the armed forces' perception of specific risks mentioned in the survey.

Figure 2 shows that, among the three potential risks, the one referring to "social media use placing soldiers at risk by revealing sensitive information" collects the greatest number of agreements. Fewer perceive a risk that the armed forces might lose control and information might become distorted. Social media has opened the field of communication to new actors, each with the potential and capability of giving different accounts of an event, posting different images of an institution, or purposefully publishing false information worldwide. Yet several armed forces, such as Sweden, the Netherlands and Italy, say that they see no such risks with social media use in an area of deployment. Rather, the most commonly perceived risks are those related to the security of soldiers, and then, the risk of harming mission purpose.

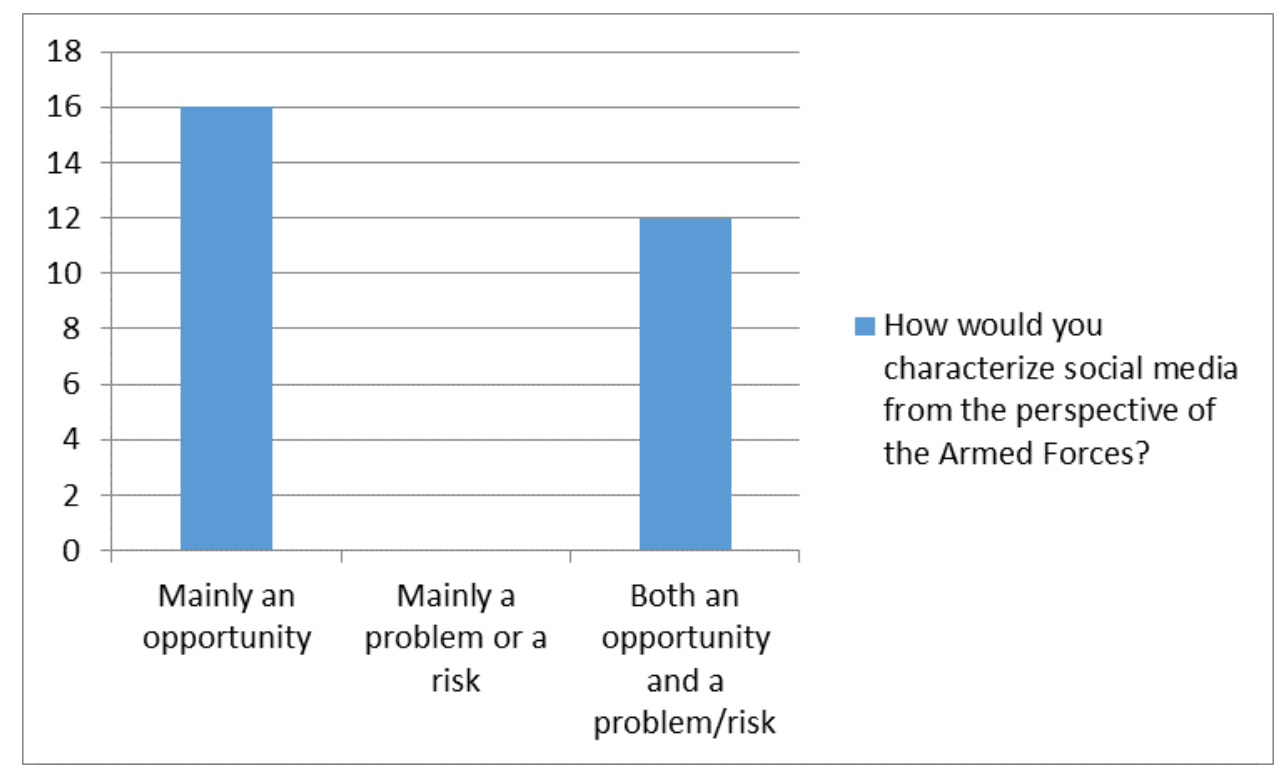

Figure 1. Views on social media as mainly a risk or as an opportunity. 


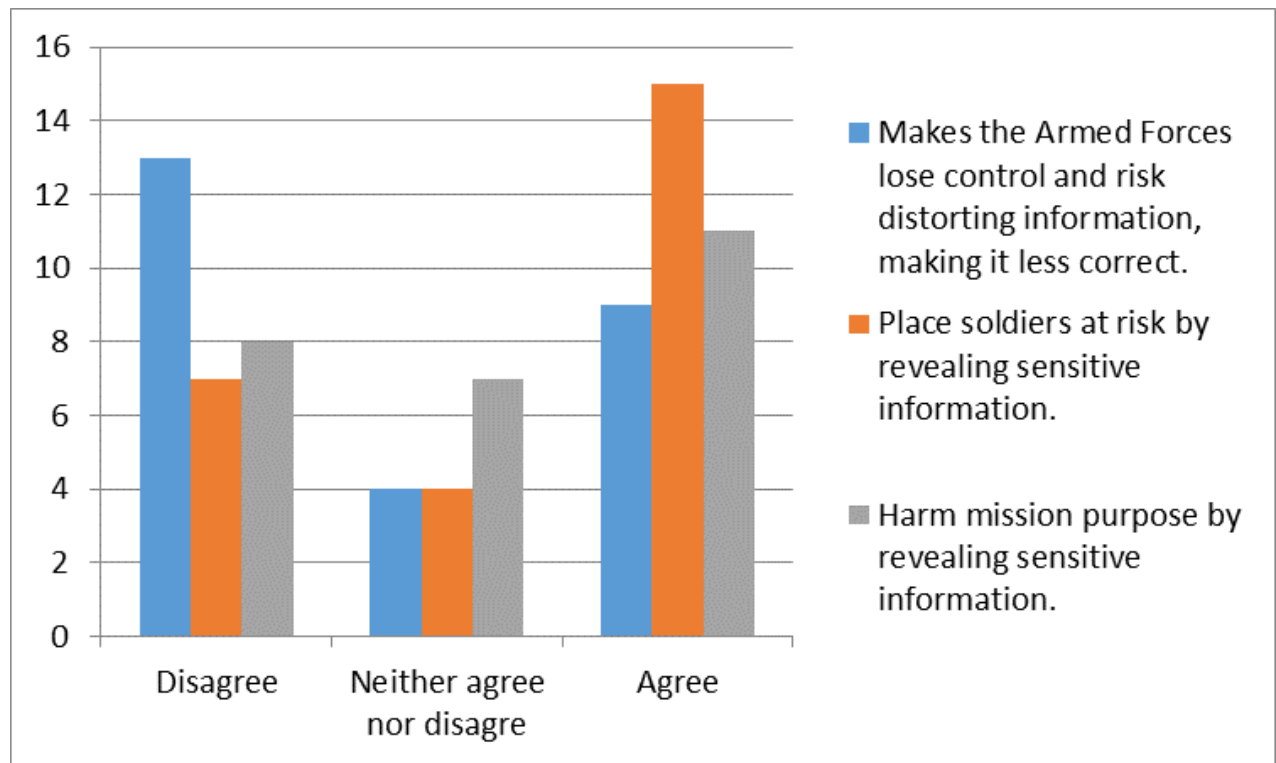

Figure 2. Risks with using social media.

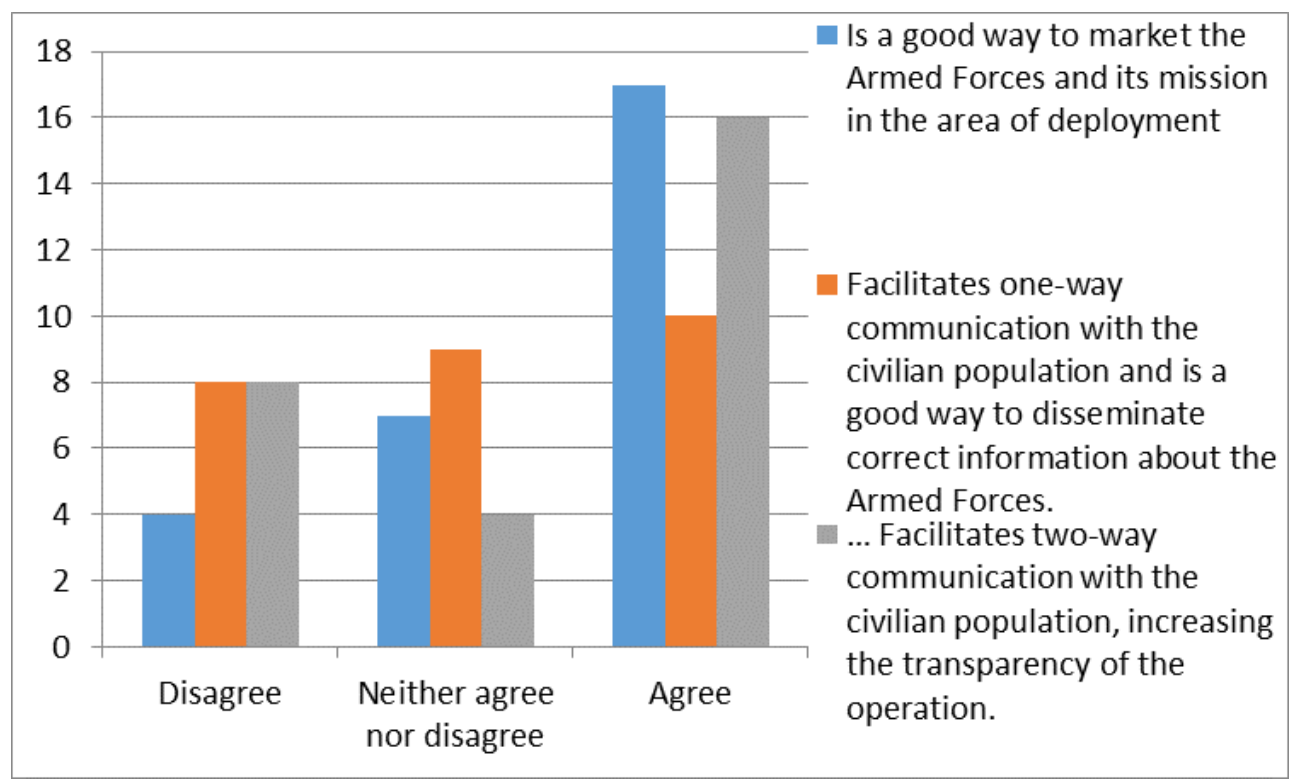

Figure 3. Opportunities with using social media.

In Figure 3 we examine how armed forces perceive the opportunities provided by social media use.

Figure 3 shows that most armed forces see social media use as beneficial for marketing purposes and for two-way communication with the civilian population. Fewer armed forces are convinced that social media facilitates one-way communication with the civilian population and is a good way to disseminate correct information. This may indicate that few armed forces are convinced that social media can replace traditional media for informing and one-way communication with local populations in areas of deployments.

We now move on to explore if the existence of a social media strategy and the national level of ICT maturity influence armed forces' perceptions of social media as a threat or an opportunity.

\subsection{How ICT Maturity Relates to Perceptions of} Opportunity and Risk in Social Media Use in European Armed Forces

We start by examining risks and opportunities on an aggregated level in relation to national ICT levels (see Table 1).

As can be seen from the table, there are only minor differences between the three groups of armed forces, yet armed forces in countries with high ICT maturity perceive risks as less severe as compared to their counterparts within countries with low ICT maturity. Next we analyzed perceptions of opportunities on an aggregated level, as shown in Table 2.

Again, we can see that there are no major differences between the groups when it comes to opportunities on 
Table 1. Risks related to experiences of international deployments.

\begin{tabular}{lllllll}
\hline & \multicolumn{2}{l}{$\begin{array}{l}\text { Extensive experience of } \\
\text { troop deployment }\end{array}$} & \multicolumn{2}{l}{$\begin{array}{l}\text { Moderate experience of } \\
\text { troop deployment }\end{array}$} & \multicolumn{2}{l}{$\begin{array}{l}\text { Minor experience of } \\
\text { troop deployment }\end{array}$} \\
\hline & $\begin{array}{l}\text { Total for all } \\
\text { armed forces }\end{array}$ & $\begin{array}{l}\text { Average per } \\
\text { individual } \\
\text { armed forces }\end{array}$ & $\begin{array}{l}\text { Total for all } \\
\text { armed forces }\end{array}$ & $\begin{array}{l}\text { Average per } \\
\text { individual } \\
\text { armed forces }\end{array}$ & $\begin{array}{l}\text { Total for all } \\
\text { armed forces }\end{array}$ & $\begin{array}{l}\text { Average per } \\
\text { individual } \\
\text { armed forces }\end{array}$ \\
\hline Risk assessment & 85 & 10,6 & 75 & 7,5 & 64 & 8,0 \\
\hline
\end{tabular}

Table 2. Opportunities related to experiences of international deployments.

\begin{tabular}{|c|c|c|c|c|c|c|}
\hline & \multicolumn{2}{|c|}{$\begin{array}{l}\text { Extensive experience of } \\
\text { troop deployment }\end{array}$} & \multicolumn{2}{|c|}{$\begin{array}{l}\text { Moderate experience of } \\
\text { troop deployment }\end{array}$} & \multicolumn{2}{|c|}{$\begin{array}{l}\text { Minor experience of } \\
\text { troop deployment }\end{array}$} \\
\hline & $\begin{array}{l}\text { Total for all } \\
\text { armed forces }\end{array}$ & $\begin{array}{l}\text { Average per } \\
\text { individual } \\
\text { armed forces }\end{array}$ & $\begin{array}{l}\text { Total for all } \\
\text { armed forces }\end{array}$ & $\begin{array}{l}\text { Average per } \\
\text { individual } \\
\text { armed forces }\end{array}$ & $\begin{array}{l}\text { Total for all } \\
\text { armed forces }\end{array}$ & $\begin{array}{l}\text { Average per } \\
\text { individual } \\
\text { armed forces }\end{array}$ \\
\hline $\begin{array}{l}\text { Opportunity } \\
\text { assessment }\end{array}$ & 74 & 9,3 & 114 & 11,4 & 69 & 8,6 \\
\hline
\end{tabular}

Table 3. Experience of international deployment related to the proposition "Social media use in an area of deployment place soldiers at risk by revealing sensitive information".

\begin{tabular}{lllll}
\hline & Disagree & Neither disagree or agree & Agree & Row total \\
\hline Extensive experience of troop deployment & 1 & - & 7 & 8 \\
Moderate experience of troop deployment & 3 & 2 & 5 & 10 \\
Minor experience of troop deployment & 3 & 2 & 3 & 8 \\
Column total & 7 & 4 & 15 & 26 \\
\hline
\end{tabular}

an aggregated level. Yet, when looking at the three potential opportunities separately (see Table 3), the analysis shows that all but one of the armed forces in countries with high ICT maturity emphasize social media use as a good way to market the armed forces and its mission-and none of the armed forces in this group disagrees. Most armed forces in countries with moderate ICT maturity also view marketing as an opportunity, although a few disagree.

Based on the Table 3, we conclude that armed forces from countries with moderate and high ICT maturity are more optimistic when it comes to using social media for marketing purposes. Thus, it seems that moderate or high ICT maturity is required in armed forces' home countries for them to view social media as suitable for projecting a favorable image of missions and troops.

In the next section we examine how social media strategies impact on the perception of social media as a threat or opportunity.

\subsection{How the Existence of an Official Social Media Strategy Relates to Perceptions of Social Media Use in European Armed Forces}

Here we analyze how a social media strategy relates to perceptions of risks and opportunities. It was found that armed forces from countries with the lowest level of ICT maturity (such as Croatia and Bulgaria) also lack a social media strategy. Yet, of those armed forces from countries with high ICT maturity, only the UK and Denmark have issued an official social media strategy.
Again, we start by showing the aggregated results based on all three risk factors.

As can be seen from Table 4, we discerned no clear results at the aggregated level when it comes to risk perceptions. Moving onto the independent analysis of each of the three risks, we also did not notice any clear patterns, yet some small differences among armed forces are worth considering (see Table 5).

As the table shows, all but two of the armed forces with a social media strategy acknowledge that soldiers might be placed at risk through social media use. In the group of armed forces lacking a social media strategy views on this risk-factor are more evenly distributed with some (Sweden, Slovenia, Latvia and the Netherlands) not considering this a risk, while others (Denmark, Germany, Poland, Bulgaria, Rumania, Portugal and Slovakia) acknowledge this to be a risk. In Table 6 we move on to analyzing the opportunities at the aggregated level.

As seen from the table, there are no clear results when examining opportunities at the aggregated level.

As can be seen from Table 7, among the opportunities, the most interesting one is marketing. For armed forces lacking a social media strategy, on third agrees that social media are a good way to market armed forces and their mission in an area of deployment, whereas only one out of five armed forces with a social media strategy agrees to this. It seems that armed forces that have not adopted a social media strategy are somewhat more prone to conceive of marketing opportunities. These are however small differences that should not be exaggerated. 
Table 4. Risks related to ICT maturity.

\begin{tabular}{|c|c|c|c|c|c|c|}
\hline & \multicolumn{2}{|c|}{ High ICT maturity } & \multicolumn{2}{|c|}{ Moderate ICT maturity } & \multicolumn{2}{|c|}{ Low ICT maturity } \\
\hline & $\begin{array}{l}\text { Total for all } \\
\text { armed } \\
\text { forces }\end{array}$ & $\begin{array}{l}\text { Average per } \\
\text { individual } \\
\text { armed } \\
\text { forces }\end{array}$ & $\begin{array}{l}\text { Total for all } \\
\text { armed } \\
\text { forces }\end{array}$ & $\begin{array}{l}\text { Average per } \\
\text { individual } \\
\text { armed } \\
\text { forces }\end{array}$ & $\begin{array}{l}\text { Total for all } \\
\text { armed } \\
\text { forces }\end{array}$ & $\begin{array}{l}\text { Average per } \\
\text { individual } \\
\text { armed } \\
\text { forces }\end{array}$ \\
\hline Risk assessment & 44 & 7,3 & 108 & 9,0 & 84 & 10,5 \\
\hline
\end{tabular}

Table 5. Opportunities related to ICT maturity.

\begin{tabular}{lllllll}
\hline & \multicolumn{2}{l}{ High ICT maturity } & Moderate ICT maturity & Low ICT maturity \\
\hline & $\begin{array}{l}\text { Total for all } \\
\text { armed } \\
\text { forces }\end{array}$ & $\begin{array}{l}\text { Average per } \\
\text { individual } \\
\text { armed } \\
\text { forces }\end{array}$ & $\begin{array}{l}\text { Total for all } \\
\text { armed } \\
\text { forces }\end{array}$ & $\begin{array}{l}\text { Average per } \\
\text { individual } \\
\text { armed } \\
\text { forces }\end{array}$ & $\begin{array}{l}\text { Total for all } \\
\text { armed } \\
\text { forces }\end{array}$ & $\begin{array}{l}\text { Average per } \\
\text { individual } \\
\text { armed } \\
\text { forces }\end{array}$ \\
\hline $\begin{array}{l}\text { Opportunity } \\
\text { assessment }\end{array}$ & 65 & 9,2 & 126 & 10,5 & 69 & 8,6 \\
\hline
\end{tabular}

Table 6. Social media use as a good way to market the armed forces and its mission in the area of deployment related to ICT maturity.

\begin{tabular}{lllll}
\hline & Disagree & Neither disagree or agree & Agree & Row total \\
\hline High ICT maturity & - & 1 & 5 & 6 \\
Moderate ICT maturity & 2 & 3 & 7 & 12 \\
Low ICT maturity & 2 & 3 & 3 & 8 \\
Column total & 4 & 7 & 15 & 26 \\
\hline
\end{tabular}

Table 7. Risks related to the existence of a social media strategy.

\begin{tabular}{lllll}
\hline & \multicolumn{2}{l}{ Having issued a social media strategy } & \multicolumn{2}{l}{ Not having issued a social media strategy } \\
\hline & Total for all & Average per individual & Total for all & Average per individual \\
& armed forces & armed forces & armed forces & armed forces \\
Risk assessment & 109 & 10,0 & 118 & 7,9 \\
\hline
\end{tabular}

\section{Conclusions}

The results of the analysis of EU armed forces' perceptions of risks and opportunities from social media use in areas of deployment show that armed forces embrace social media as an opportunity more than they emphasize the risks. The most commonly perceived opportunities are marketing and two-way communication. Fewer appreciate the opportunity of using social media for one-way communication. The focus on marketing and PR corresponds with the point made in the introduction (e.g. Byrkjeflot \& Angell, 2007) about a general tendency within public organizations to increasingly focus on marketing. Armed forces appear to follow this trend.

While none of the armed forces view social media primarily as a problem or risk, half of the armed forces acknowledge that the use of social media does involve risks. When asked to assess specific risks, the probability that social media use places soldiers at risk, by revealing sensitive information, is most common. Somewhat surprisingly, the risk of social media use distorting information, making it less correct, is acknowledged by fewer armed forces. As argued in the section on previ- ous research, academics have dealt with armed forces' preoccupation with control of the strategic narrative (e.g. Bjerg Jensen, 2011), yet our results indicate that the risk of distorting information is not seen as the major problem with social media use in areas of deployment. This indicates that armed forces more often focus on the dangers of social media in relation to the safety of military personnel (e.g. Maltby et al., 2015, p. 17), rather than on the risk that they interfere with or distort their strategic narrative.

Furthermore, we explored whether or not views on opportunities and risks were related to the existence of a social media strategy and ICT maturity. In terms of ICT maturity, we found that all armed forces but one, from countries where ICT maturity is moderate or high, consider marketing an opportunity provided by social media use. Among armed forces from countries with the lowest ICT maturity views are divided. This contradicts previous research stating that the use of social media by governmental agencies does not correspond to the national level of ICT maturity (Bonsón et al., 2012). At least, it seems that ICT maturity does matter when it comes to armed forces' views on social media use. Also, we found that armed forces that have not adopted a social media 
strategy are somewhat more positive towards using social media for marketing purposes.

Finally, as recognized above, we only investigated armed forces' viewpoints at the strategic level and, as argued above, more research is needed to provide a more complete picture of armed forces' views of social media in peacekeeping operations. Moreover, recognizing that ICT maturity and a social media strategy have relatively little impact, we must investigate other factors that might explain national differences in perceptions of the risks and opportunities of social media use. Should we search for explanations in the national strategic cultures of armed forces? What role do previous negative experiences of placing personnel at risk play in deciding what measures are taken to regulate the use of social media? In contrast, how do positive experiences of social media as a marketing tool spur development towards less regulation and more positive views on social media? Further research with more refined questionnaires and/or interviews is needed to deepen our understanding of the attitudes of armed forces towards the use of social media.

\section{Acknowledgments}

The authors are greatly indebted to MA Rickard Blomstrand for his great work in assembling the empirical data.

\section{Conflicts of interest}

The authors declare no conflict of interest.

\section{References}

Andén-Papadopoulos, K. (2009). US soldiers imaging the Iraq War on YouTube. Popular Communication, 7, 1727.

Bennett, D. (2013). Exploring the impact of an evolving war and terror blogosphere on traditional media coverage of conflict. Media, War \& Conflict, 6(1), 3753.

Bertot, J. C., Jaeger, P. T., \& Grimes, J. M. (2010). Using ICTs to create a culture of transparency: Egovernment and social media as openness and anticorruption tools for societies. Government information quarterly, 27(3), 264-271.

Betz, D. (2008). The virtual dimension of contemporary insurgency and counterinsurgency. Small Wars \& Insurgencies, 19(4), 510-540.

Bjerg Jensen, R. (2011). British military media strategies in modern wars. Global Media and Communication, 7, 193-197.

Bjerg Jensen, R. (2014). Managing perceptions: Strategic communication and the story of success in Libya. In K. Engelbrekt, M. Mohlin, \& C. Wagnsson (Eds.), The NATO intervention in Libya: Lessons learned from the campaign (pp. 171-194). Abingdon, UK: Routledge.

Bonsón, E., Torres, L., Royo, S., \& Flores, F. (2012). Local e-government 2.0: Social media and corporate transparency in municipalities. Government information quarterly, 29(2), 123-132.

Byrkjeflot, H., \& Angell, S. (2007). Dressing up hospitals as enterprises? The expansion and managerialization of communication in Norwegian hospitals. In P. Kjær \& T. Slaatta (Eds.), The media-embedded firm (pp. 81-113). Copenhagen: Copenhagen Business Press.

Caldwell, B., Murphy D. M., \& Menning, A. (2009). Learning to leverage new media. The Israeli defense forces in recent conflicts. Military Review, May-June 2009.

Cammaerts, B. (2008). Critiques on the participatory potentials of Web 2.0. Communication, Culture \& Critique, 1(4), 358-377.

Cammaerts, B., \& Carpentier, N. (2009). Blogging the 2003 Iraq War: Challenging the ideological model of war and mainstream journalism? Observatorio (OBS*), 9, 1-23.

COMISAF's Initial Assessment (September 21, 2009). The Washington Post. Retrieved from http://www. washingtonpost.com/wp-dyn/content/article/2009/ 09/21/AR2009092100110.html

Deverell, E., Olsson, E., Wagnsson, C., Johnsson, M., \& Hellman, M. (2015). Understanding public agency communication: The case of the Swedish Armed Forces. Journal of Public Affairs, 15(4), 387-396.

Dimitru, G. R. (2012). Winning the story war: Strategic communication and the conflict in Afghanistan. Public Relations Review, 38(2), 195-207.

Dunleavy, P., Margetts, H., Bastows, S., Tinkler, J. (2006). New public management is dead. Long live digital-era governance. Journal of Public Administration Research and Theory, 16, 467-494.

Forster, A. (2006). Armed forces and society in Europe. London: Palgrave.

Hellman, M., \& Wagnsson, C. (2015). New media and the war in Afghanistan: The significance of blogging for the Swedish strategic narrative. New Media and Society, 17(1), 6-23.

International Telecommunication Union. (2015). Core indicators on access to and use of ICT by households and individuals. ITU. Retrieved from http://www. itu.int/en/ITU-D/Statistics/Pages/stat/default.aspx

Jankowski, B. (2013). War narratives in a world of global information age France and the War in Afghanistan (Paris Papers No. 8). Paris: Institute de Recherche Stratégique de L'Ecole Militaire (IRSEM).

Jones, N., \& Baines, P. (2013). Losing control? Social media and military influence. The RUSI Journal, 158(1), 72-78.

Kahn, R., \& Kellner, D. (2004). New media and internet activism: From the 'Battle of Seattle' to blogging. New Media and Society, 6(1), 87-95.

Karatzogianni, A. (2008). Cyber conflict and global politics. London: Routledge. 
Lawson, S. (2014). The US military's social media civil war: Technology as antagonism in discourses of information-age conflict. Cambridge Review of International Affairs, 27(2), 226-245.

Magro, M. J. (2012). A review of social media use in egovernment. Administrative Sciences, 2(2), 148-161.

Maltby, S., Thornham, H., \& Bennett, D. (2015) Capability in the digital: Institutional media management and its dis/contents. Information, Communication \& Society. doi:10.1080/1369118X2015.1046893

Morozov, E. (2011). The net delusion. How not to liberate the world. London: Allen Lane.

Nissen, T. E. (2015). The weaponization of social media@Characteristics of contemporary conflicts. Copenhagen: Royal Danish Defense College.

Paul, C. (2012). Challenges facing US government and Department of Defense efforts in strategic communication. Public Relations Review, 38(2), 188-194.

Resteigne, D. (2010). Still connected in operations? The milblog culture. International Peacekeeping, 17(4), 515-525.

Rid, T., \& Hecker, M. (2009) War 2.0 irregular warfare in the information age. London: Prager Security International.

Ringsmose, J., \& Börgesen, B. K. (2011). Shaping public attitudes towards the deployment of military power: NATO, Afghanistan and the use of strategic narratives. European Security, 20(4), 505-528.

Shannon, C. E. (1948). A mathematical theory of communication. The Bell System Technical Journal, 27, 379-423.

Wæraas, A. 2010. Communicating identity: A study of core value statements in regulative institutions. $A d$ ministration \& Society, 42, 526-549. doi:10.1177/ 0095399710377435

Wall, M. (2006). Blogging Gulf War II. Journalism Studies, 7(1), 111-126.

\section{About the Authors}
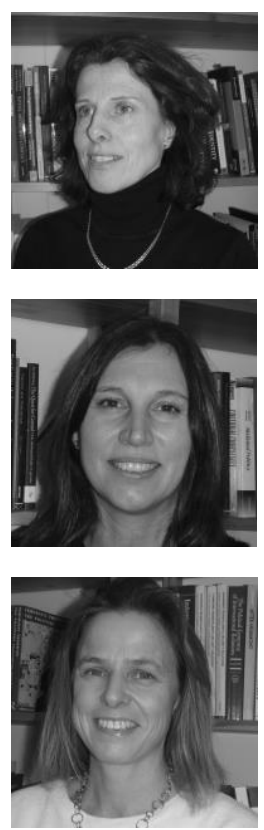

Dr. Maria Hellman

Maria Hellman is Lecturer of Political Science at the Swedish Defence University. Her research interests include political communication and global media studies. She has published her work in journals such as Media, War and Conflict and International Journal of Cultural Studies.

\section{Dr. Eva-Karin Olsson}

Eva-Karin Olsson is an Associate Professor of Political Science at the Swedish Defence University. Her research interests include crisis management, political communication and international organizations. She has published her work in journals such as Journalism, International Journal of Press/Politics, Public Administration, and Media, War and Conflict.

\section{Dr. Charlotte Wagnsson}

Charlotte Wagnsson is Professor of Political Science at the Swedish Defence University. Her research interests include European security and political communication. She has published her work at Routledge and Manchester University Press and in journals such as New Media and Society, Cooperation and Conflict and Journal of European Public Policy. 


\section{Appendix}

Please note that a few more questions were included in the questionnaire, but since they did not form part of the analysis of this article they are not listed below.

Questionnaire on the Armed Forces' social media strategy

Introduction

The questionnaire forms part of the research project "Social media strategies of Armed Forces" conducted by five postgraduate scholars of war studies and political science at the Swedish National Defense University. The aim is to analyze how Armed Forces from states forming part of NATO and/or the EU looks upon the use of social media in connection with military missions abroad as well as everyday work at home. Since there is limited data on how the armed forces make use of social media we would like to generate deeper knowledge in this field.

In order to gather this data we would very much appreciate the cooperation of a person responsible for the social media strategy of Armed Forces (Head of Information Department or its equivalent) to answer the survey. The answers are anonymous.

What is your current position?

Representative of Information Department of the Armed Forces

Representative of Ministry of Defense

Other position, yet with tasks related to the Armed Forces' information and communication

$\underline{\text { Use of social media by the Armed Forces }}$

Do the Armed Forces officially make use of the following social media:

Yes No Do not know

Facebook

You Tube

Twitter

Blogging

Instagram

Other (please specify)

How active are the Armed Forces on social media?

Make use of social media daily

Make use of social media weekly

Make use of social media monthly

Do not know

How would you characterize social media from the perspective of the Armed Forces:

Mainly an opportunity 
Mainly a problem or a risk

Both an opportunity and a problem/risk

$\underline{\text { Has the Armed Forces officially issued a social media strategy? }}$

Yes

No

If yes, please name the year of issue.

If the Armed Forces are about to issue such a strategy, please name the year of its planned release

To what degree do you agree with the following statements about use of social media in an area of deployment (for example Afghanistan)

Not agree-Wholly agree on a 1-5 scale. 3=Neither agree nor disagree

Personnel stationed in an area of deployment (for example Afghanistan) using social media platforms (for example blogs):

Makes the Armed Forces lose control and risk distorting information, making it less correct

Place soldiers at risk by revealing sensitive information

Harm mission purpose by revealing sensitive information

Is a good way to market the Armed Forces and its mission in the area of deployment

Facilitates one-way communication with the civilian population and is a good way to disseminate correct information about the Armed Forces

Facilitate two-way communication with the civilian population, increasing the transparency of the operation

Among the following options, what is the greatest advantage with using social media by the Armed Forces and its personnel stationed in an area of deployment? Please rank from 1 to 3.

Use of social media of the Armed Forces and its personnel in an era of deployment...

Is a good way to market the Armed Forces and its mission in the area of deployment

Facilitates one-way communication with the civilian population and is a good way to disseminate correct information about the Armed Forces

Facilitate two-way communication with the civilian population, increasing the transparency of the operation

Please mention other negative aspects of social media (if you see any other risks with the Armed forces or its military personnel using social media platforms)

Please mention other positive aspects of social media (if you see any advantages with the Armed Forces or its military personnel using social media platforms) 